UDK: 791.43.091:821.134.2(82)-32 Кортасар X. DOI: https://doi.org/10.18485/legado_hispanico.2020.ch11

\author{
Ксенија Вранеш ${ }^{1}$ \\ Универзитет у Београду \\ Србија
}

\title{
КОРТАСАРОВ „АУТО-ПУТ ЗА ЈУГ“ НА ФИЛМУ ИЛИ АДАПТАЦИЈЕ КОЈЕ ТО МОЖДА НИСУ
}

\begin{abstract}
Резиме
Годаров филм Викенд (1967) и Коменчинијев филм Застој (1979) у критици се најчешће сматрају адаптацијама Кортасарове приповетке „Ауто-пут за југ“ (1966). Па ипак, ни једно ни друго филмско остварење не испуњавају један од најважнијих критеријума сваке адаптације саопштење ауторове намере. Годар није познавао Кортасарову приповетку, иако се сусрео са сценаријом написаним по „Ауто-путу за југ“. Коменчини је, с друге стране, за Кортасарову приповетку чуо, али се куне да је никада није читао. У раду се трага за одговором на питање могу ли се поменути филмови, упркос томе, прогласити за адаптације на основу поетичких сличности и суда гледалаца.
\end{abstract}

Кључне речи: Хулио Кортасар, Жан-Лик Годар, Луиђи Коменчини, „Ауто-пут за југ“, Викенд, Застој, адаптација, апропријација.

${ }^{1}$ ksenija.m.vranes@gmail.com 
Још од шездесетих година 20. века дело аргентинског писца Хулија Кортасара (Julio Cortázar) инспирише бројне режисере и сценаристе. Међу првим режисерима који су били надахнути Кортасаровим приповеткама нашао се Аргентинац Мануел Антин (Manuel Antín), аутор филмских адаптација неколико Кортасарових прича. Приповетку „Мамина писма“ (шп. «Cartas de mamá», 1959) Антин је преобликовао у филм Непарна цифра (шп. La cifra impar, 1962), „Кирку“ (шп. «Сirce», 1951) је 1964. године адаптирао у истоимени филм, а приповетке „Идол Киклада“ (шп. «El ídolo de las Cícladas», 1956) и „Континуитет паркова“ (шп. «Continuidad de los parques», 1964) послужиле су као предлошци за филм Интимност паркова (шп. Intimidad de los parques) из 1965. године (Маје 1985: 182; Фернандес \& Сабанес 2014: 105-106). Исте године се још један аргентински режисер, Осијас Виленски (Osías Wilensky), одлучује да адаптира Кортасарову приповетку „Прогонитељ“ (шп. «El perseguidor», 1959) у истоимени филм, а први међународни и засигурно најзапаженији пример адаптације Кортасаровог текста била је појава филма Увећање (енг. Blow-up, 1966) Микеланђела Антонионија (Michelangelo Antonioni) инспирисана приповетком „Бавоље бале“ (шп. «Las babas del diablo», 1959).

Нестор Тири (Néstor Tirri) и Сара Винокур де Тири (Sara Vinocur de Tirri), аутори предговора за један од првих зборника посвећених делу Хулија Кортасара из 1968. године, сматрају да управо ови филмови снимљени шездесетих година 20. века «testimonian estadísticamente» ${ }^{2}$ да је Кортасар један од писаца Хиспанске Америке чија дела се најчешће бирају да буду «traducidos en imágenes» ${ }^{3}$ (Тири \& Винокур де Тири 1968: 8). До почетка 21. века ова тврдња се до те мере усталила да је, како примећује Лопес Пецолт (2014: 13), 2007. године без икакве додатне аргументације наведена на корицама антологије Кортасарових екранизованих приповедака, и то проширена на читаво шпанско говорно подручје: «Julio Cortázar es, sin duda, uno de los autores en lengua española con más adaptaciones cinematográficas.» ${ }^{4}$ (Кортасар 2007: s. p.) Очигледна ефектност ове реченице, као и њен аксиоматски статус, потврђени су њеним поновним укључивањем у текст на корицама наредна два издања

\footnotetext{
${ }^{2}$ „статистички сведоче“ (сви преводи су ауторски).

3 „преведена у слике“.

4 „Хулио Кортасар је, без сумње, један од писаца на шпанском језику са највише филмских адаптација."
} 
ове збирке, 2009. и 2011. године. ${ }^{5}$ На тим истим корицама посебна пажња се поклања приповеци „Ауто-пут за југ“ (шп. "Autopista del sur», 1966) за коју се каже да је «uno de los relatos más conocidos del autor y que fue llevado al cine por partida doble nada menos que por Jean-Luc Godard (Week end [sic]) y por Luigi Comencini (El gran atasco [sic]) $»^{6}$ (Кортасар 2009; Кортасар 2011).

Могло би се претпоставити да је двојицу веома ангажованих режисера, као што су Жан-Лик Годар и Луиђи Коменчини, Кортасаровој приповеци „Ауто-путу за југ“ привукао управо велики интерпретативни потенцијал снажне осуде западног капиталистичког друштва, која је у њој присутна. Основна линија заплета Кортасарове приповетке полази од ситуације врло познате Парижанима који су лети викендима одлазили на југ, а недељом по подне, враћајући се у Париз, суочавали се с вишечасовним застојима на улазу у град (Гонсалес Ећеварија 1971: 135). У средишту радње налази се скупина људи који током вишемесечног застоја на путу стварају неку врсту примордијалне заједнице. Међутим, чим се колона аутомобила покрене, заједница се растура и сви њени учесници настављају са својом свакодневном јурњавом без циља. Заједница која настаје између возача аутомобила заустављених у колони могла би се окарактерисати као неки облик примитивног друштва (Гонсалес Ећеварија 1971: 137): заснива се на сакупљању и размени добара с другим заједницама, негује ритуални однос према смрти и задовољење базичних људских потреба представља императив за све њене чланове. Ипак, брига за добробит чланова заједнице коју већина возача испољава, као и сам начин организације овог малог друштва, наводила је критичаре да Кортасарову причу назову «[una] utopía socialista» ${ }^{7}$ (Ескудеро-Али 2006), и да у критици друштва препознају кључну тему Кортасаровог текста (Гонсалес Ећеварија 1971: 136; Ескудеро-Али 2006; Ламберт 2014), с главним подтемама у критици алијенације у друштву (Ђурко 1974: 49; Ескудеро-Али 2006; Гонсалес Ећеварија 1971: 136; Мартинес Аријас

\footnotetext{
${ }^{5}$ Антологија Филмске приче (шп. Cuentos de película) из 2007. године и збирка Прогонитељ и друге филмске приче (шп. El perseguidor у otros cuentos de cine, прво издање 2009. године, а друго 2011.) заправо представљају различита издања исте књиге. Упоредити: Кортасар 2007; Кортасар 2009; Кортасар 2011.

6 „једна од најпознатијих приповедака овог аутора коју су два пута пренели на велико платно и то нико други до Жан-Лик Годар (Викенд) и Луиђи Коменчини (Велики застој)“.

${ }^{7}$ „социјалистичком утопијом“.
} 
2015: 221) и протесту против опште дехуманизације савременог живота (Матас 1973: 602).

Годаров Викенд (фр. Week-end) премијерно је приказан крајем 1967. године (Ферфакс 2017) и отада слови за један од најреволуционарнијих филмова француског режисера. Викенд истовремено представља тренутак Годаровог раскида с пређашњим стваралаштвом и окретања ка такозваним анархистичким филмовима (Езел 2012). У Годаровом филму млади брачни пар из Париза полази на југ како би осигурао породично наслеђе. Док јуре ка свом фарисејском циљу, брачни партнери наилазе на фантастичну колону аутомобила, апокалиптичне призоре и бизарне појаве (Ферфакс 2017). Отуда је овај филм називан «Godard's bloody extravaganza» ${ }^{8}$ (Гонсалес Ећеварија 1971: 131), «una crítica a la burguesía y sus vericuetos morales» ${ }^{9}$ (Седењо Валдељос 2014: 87) и приказом «the absurdity of the life created by capitalism ${ }^{10}$ (Езел 2012).

Једанаест година касније Луићи Коменчини снима филм Застој, немогућа прича (ит. L'ingorgo, una storia impossibile), који ће на пролеће 1979. почети да се приказује у биоскопима. Коменчинијев филм говори о саобраћајном хаосу који наступа на ауто-путу ка Риму када стотине аутомобила остану у целодневном застоју. Гледаоци се упознају с мноштвом различитих ликова који у затеченој ситуацији махом испољавају бес, егоизам, похоту, незаинтересованост за друге, насиље и фарисејство. После ноћи проведене у застоју изгледа као да ће се колоне покренути, али аутомобили ипак остају непомични до краја одјавне шпице. Из тог разлога су критичари закључили да је Коменчинијев филм «uncovered the social malaise of Italian affluence» ${ }^{11}$ (Молитерно 2008: 89), и представио «una radiografia dell'Italia» $^{12}$ (Гили 2004: 91), «el absurdo de la sociedad capitalista contemporánea» ${ }^{13}$ (Фpejpe 2013), «the drawbacks and the darker sides of mass consumption» ${ }^{14}$ (Фулвуд 2015: 142) и «a rather bleak view of the humanity» ${ }^{15}$ (Руго 2016: 145).

\footnotetext{
8 „Годаровом крвавом екстраваганцијом“.

${ }^{9}$ „критиком буржоазије и њених моралних наличја“.

10 „апсурдности живота који ствара капитализам“.

11 „открио друштвену слабост италијанског благостања“.

12 „рендгенски снимак Италије“.

13 „апсурд савременог капиталистичког друштва“.

14 „недостатке и мрачне стране масовне потрошње“.

15 „прилично туробну визију човечанства“.
} 
Ни публика ни критичари нису имали сумње да су Викенд и Застој адаптације Кортасарове приповетке „Ауто-пут за југ“ (Руго 2016: 144; Данијеле 2016: 12; Кесада Вакеро 2017: 113), без обзира на различите закључке о њиховој верности и квалитету. Мишљења о Годаровом Викенду као адаптацији Кортасаровог „Ауто-пута за југ“ била су посве опречна и кретала се од става да постоји суштинска блискост филма и приче (Болте 2019: 242-243) до тврдњи да Годаров филм није пренео суштину духа и атмосфере Кортасаровог текста (Кесада Вакеро 2017: 117). Било је и ставова да је Викенд изневерио текст који наводно адаптира, или да је заправо само једна секвенца филма инспирисана Кортасаровом приповетком (Вита 2012; Лопес Пецолт 2014: 363). С друге стране, Коменчинијев Застој без изузетка је препознат као верна адаптација Кортасаровог „Аутопута за југ“ (Кенби 1988: С.14; Нејферт 2003: 363; Фурније Ланцони 2008: 220; Галван 2014; Лопес Пецолт 2014: 244), па чак и као «[u] na de las mejores adaptaciones cinematográficas de [las obras de] Julio Cortázar» ${ }^{16}$ (Кесада Вакеро 2017: 117).

Па ипак, занимљиво је да ниједан од двојице режисера не помиње да је био инспирисан Кортасаровом приповетком ни у уводној, ни у одјавној шпици свог филма. Поред тога, ни у Годаровом Викенду, ни у Коменчинијевом Застоју не могу се пронаћи директни и несумњиви Кортасарови утицаји, попут имена ликова или директно преузетих специфичних елемената заплета. Објашњење за ову појаву у Годаровом случају дао је сам Кортасар у писму преводитељки Сузан Џил Левин (Suzanne Jill Levine) од 30. јуна 1972. године, образлажући зашто не жели да његова збирка приповедака Све ватре ватра (Todos los fuegos el fuego, 1966), у којој је објављен „Ауто-пут за југ”, у енглеском издању носи наслов Викенд:

En efecto, la película de Godard se inspiró en «La autopista del sur», pero de una manera muy poco honesta, no por culpa de Godard que no estaba enterado de nada, sino por alguien que, según parece, conoció otro script con el cual un productor inglés pensaba filmar «La autopista», y le llevó la idea a Godard como si fuera propia, y naturalmente sin mencionarme. [...] [E]l inglés no hizo nunca su film y yo no cobré ni un céntimo por esa adaptación que Godard llevó a cabo con toda inocencia. Todas esas razones me impiden aceptar Week-End como título; si yo hubiera participado en el film de Godard estaría naturalmente de acuerdo [...] pero no veo por qué

\footnotetext{
16 „једна од најбољих филмских адаптација [дела] Хулија Кортасара“.
} 
tengo que copiar un título de Godard, después que él me copió a mí la idea de un relato, sin culpa suya (Кортасар 2012b: 292). ${ }^{17}$

Судећи по Кортасаровим речима, Годар се није инспирисао директно текстом приповетке „Ауто-пут за југ“, већ њеном прерадом за непознати сценарио. ${ }^{18}$ У том случају Викенд би се у најбољем случају могао описати као адаптација у другом степену ${ }^{19}$ : адаптација „Ауто-пута за југ“ посредством другог текста.

Док се Годар, колико нам је познато, није изјашњавао поводом Кортасарових тврдњи, Коменчини је децидно тврдио да никада није ни прочитао „Ауто-пут за југ“: «Giuro in buona fede di non aver mai letto il racconto di Cortázar su un ingorgo alle porte di Parigi. Sapevo que esisteva, ho preso una raccolta di racconti di Cortázar e quel racconto non c'era, non c'è piu, e non ho mai potuto leggerlo.» ${ }^{20}$ (Коменчини apud Фалдини \& Фофи 1984: 302) Коменчини се, додуше, могао инспирисати Кортасаровом приповетком из „треће руке“. Имајући у виду значај Годара унутар француског новог таласа (фр. la Nouvelle Vague) и афинитет италијанског режисера према теми застоја на путу и друштвеној критици, мало је вероватно да се Коменчини није сусрео с филмом Викенд. Претворен у сценарио који је вероватно

17 Годаров филм у ствари јесте инспирисан 'Ауто-путем за југ', али на прилично
непоштен начин, не Годаровом кривицом, који није био упућен ни у шта, већ зато
што је неко, како се чини, знао за други script по ком је један енглески продуцент
намеравао да сними 'Ауто-пут', и изнео идеју Годару као да је његова лична, наравно
не помињући ме. [...] [E]нглез никада није снимио свој филм и ја нисам добио ни
паре од адаптације коју је Годар снимио ни крив ни дужан. Сви ови разлози ме
спречавају да прихватим наслов Викенд; да сам учествовао у Годаровом филму,
био бих, наравно, сагласан [...] али не видим зашто бих морао да копирам Годаров
наслов, пошто је он од мене копирао идеју једне приче, иако није крив.

18 Кортасар ни у једном тренутку не прецизира о сценарију је реч, али би се могло претпоставити да је у питању сценарио који је Гиљермо Кабрера Инфанте (Guillermo Cabrera Infante) под псеудонимом Г. Каин (G. Caín) написао одмах по појављивању приповетке (Кортасар 2012а: 351), али који никада није реализован упркос занимању бројних режисера. За више података о судбини овог сценарија, као и Кортасаровог пријатељства с Кабрером Инфантеом, видети: Фернандес 2014; Пералес Контрерас 2014; Грас 2016; Грас 2019.

19 Занимљиво је да се управо у опису паратекста у Женетовој (Genette) књизи Палимпсести: књижевност у другом степену (фр. Palimpsestes: la littérature au second degré) Томас Лајч (2012: 97) препознаје једну врсту адаптације (в. Женет 1982: 9), или барем изузетно инспиративан текст за теорију адаптације.

20 „Кунем се у доброј вери да никада нисам прочитао Кортасарову причу о застоју на путу пред улазом у Париз. Знао сам да постоји, узео сам једну Кортасарову збирку прича и те приче ту није било, и даље је нема и никада је нисам могао прочитати.“ 
инспирисао Годаров Викенд, „Ауто-пут за југ“ би у том случају даље потенцијално утицао на Коменчинијев Застој. Ипак, питање је да ли превише несвесних и посредних утицаја у теоријском смислу онемогућава да се Викенд и Застој с пуним правом назову адаптацијама.

Појам „адаптације“ савремена теорија третира на веома различите начине: као трансфер наратива из књижевног у филмски медијум (Мекфарлан 2007: 19), «counter-ekphrases» ${ }^{21}$ (Лајч 2012: 92), «examples of a distinctive mode of transtextuality» ${ }^{22}$ (Лајч 2012: 96), дословни, традиционални или радикални превод књижевности у филм (Кахир 2006: 16-17). Џули Сандерс (Julie Sanders) тако успоставља разлику између адаптације, као директног и непосредног преобликовања књижевности у филм, и апропријације, која остварује посреднију везу с изворним текстом:

An adaptation signals a relationship with an informing text or original; a cinematic version of Shakespeare's Hamlet although clearly reinterpreted by the collaborative efforts of director, scriptwriter, actors and the generic demands of the movement from stage drama to film, remains ostensibly Hamlet [...]. On the other hand, appropriation frequently affects a more decisive journey away from the informing source into a wholly new cultural product and domain. This may or may not involve a generic shift [...]. But the appropriated text or texts are not always as clearly signalled or acknowledged as in the adaptive process. They may occur in a far less straightforward context than is evident in making a film version of a canonical play ${ }^{23}$ (Сандерс 2005: 20).

\section{Линда Хачион (Linda Hutcheon) једнако строге услове поставља} и пред адаптације, и пред апропријације. По њеном мишљењу, непризнате апропријације не могу се сврстати у домен адаптација: «Plagiarisms are not acknowledged appropriations, and sequels and

\footnotetext{
21 „обрнуте екфразе“.

22 „примере особеног облика транстекстуалности“.

${ }^{23}$ Адаптација указује на однос са изворним текстом или оригиналом; филмска верзија Шекспировог Хамлета, иако очигледно реинтерпретирана посредством удружених напора режисера, сценариста, глумаца и генеричких захтева промене из сценске драме у филм, наоко и даље остаје Хамлет [...]. С друге стране, апропријација често тежи одлучнијем удаљавању од изворног текста ка потпуно новом културном производу и сфери. То може и не мора подразумевати свеопшту промену [...]. Али у процесу апропријације на присвојени текст или текстове се не указује увек јасно нити су они јасно признати. Они се могу јавити у много мање непосредном контексту него у снимању филма по канонском комаду.
} 
prequels are not really adaptations either, nor is fan fiction.» ${ }^{24}$ (Хачион 2006: 9). Једна од најчешће цитираних дефиниција адаптације потиче управо од Линде Хачион, која од тог жанра захтева «аn extended, deliberate, announced revisitation of a particular work of art $»^{25}$ (Хачион 2006: 170). Посматрани кроз призму дефиниције Линде Хачион, Годаров и Коменчинијев филм могли би се тек делимично сврстати међу адаптације.

Док би Застој могао да одговори на први захтев дефиниције Л. Хачион, будући да представља проширење радње „Ауто-пута за југ“, Викенд већ у овом погледу не би могао да буде квалификован као адаптација. Ако се посматра сцена бескрајне колоне, једина у којој практично сви критичари виде одјек Кортасарове приповетке, Годаров филм би пре био резултат сажимања радње него њеног проширења својственог адаптацијама. Постојање ауторове намере чини се још проблематичнијим у случају Викенда и Застоја, а нема никакве сумње да ниједан од ова два филма не задовољава последњи услов Линде Хачион: саопштење ауторове намере и извора адаптације. Штавише, неиспуњавање овог услова сврстало би и Викенд и Застој, као непризнате адаптације, међу плагијате (в. Хачион 2006: 9).

Намеће се питање зашто критика доследно занемарује поменуту сугестију ЛиндеХачион и не оптужује Годара и Коменчинија за плагијат, већ им, у најгорем случају, приговара што нису навели Кортасарово име међу ауторима сценарија. Одговор се изгледа крије на очигледном, мада за проучавање посебно тешком месту, у начину на који је Годарове и Коменчинијеве филмове доживела стручна и „лаичка” публика. У теорији Линде Хачион улога гледалаца долази на самом крају, тек као потврда исправно схваћене намере режисера: «And, in the end, it is the audience who must experience the adaptation as an adaptation» ${ }^{26}$ (Хачион 2006: 172; курзив је присутан у изворном тексту). Томас Лајч (2012: 95) разрађује идеју Линде Хачион у погледу нужности присуства ауторове намере како би се неко дело сматрало адаптацијом, али и удела публике у том процесу и доноси следећи закључак: «In order for an adaptation to count as an adaptation [...] it has to meet two conditions: its creators must intend

\footnotetext{
24 „Плагијати су непризнате апропријације, ни наставци ни преднаставци нису заиста адаптације, као што није ни fanfiction."

25 „проширена, хотимична, призната ревизија неког уметничког дела“.

${ }^{26}$ „И, на крају, публика је та која мора искусити адаптацију као адаптацију“.
} 
it to be perceived as an adaptation; and its audience must so perceive it.» ${ }^{27}$ Ни Годаров ни Коменчинијев филм нису замишљени као адаптације „Ауто-пута за југ“, али је публика у њима препознала верзију Кортасарове приповетке, што би им, према Лајчу, донекле осигурало статус адаптације. У наставку рада посветићемо се анализи поетичких сличности и разлика између Кортасаровог „Ауто-пута за југ“, Годаровог Викенда ${ }^{28}$ и Коменчинијевог Застоја, настојећи да откријемо разлоге из којих се мишљење гледалаца директно супротставља намерама и ставовима режисера.

Као што је раније наглашено, основна идеја Кортасарове приповетке могла би се сажети у критику друштва (Гонсалес Ећеварија 1971: 137), и то, пре свега, критику капитализма и буржоазије, која се огледа у негативном односу према техничким достигнућима. Уместо да обезбеди напредак и брзину, ауто-пут постаје препрека (Болте 2019: 215), док се у приказу аутомобила одступа од позитивне слике својствене педесетим и шездесетим годинама 20. века. Аутомобили у Кортасаровој приповеци представљају вид поробљавања људског рода, они су ти који отуђују људе, затварају их у металне кавезе и не дозвољавају им да се зближе и повежу (Мартинес Аријас 2015: 226). Иако људима пружају слободу кретања, аутомобили им одузимају слободу избора при том кретању: возач мора да се повинује правцима путева, ограничењима брзине и другим саобраћајним законима и прописима.

Посредством критике аутомобила и сатиричног приказа власника луксузних возила, Кортасар на дискретан начин разобличава мане буржоазије. Кортасарова утопијска заједница представља микрокосмос састављен од омладине (младићи из симке), старијих људи (пар из ситроена ID), породица (у пежоу 203 и таунусу), свештенства (две часне сестре у спачеку), војних лица (војник у фолксвагену), сељака (пар из аријане) и заљубљених

\footnotetext{
27 „Како би се адаптација рачунала као адаптација [...], она мора испунити два услова: њени творци морају намеравати да она буде доживљена као адаптација; и њена публика је мора тако доживети.“

${ }^{28}$ Компаративна анализа Кортасарове приповетке и Годаровог филма делимично је заснована на излагању под насловом «Julio Cortázar у Jean-Luc Godard: una historia y dos anticipaciones de las revoluciones de 1968» [Хулио Кортасар и Жан-Лик Годар: једна прича и две антиципације револуција 1968.] саопштеном у Барселони 2018. године на међународном научном конгресу VI Congreso Internacional de Historia y Cine: Imágenes de las Revoluciones de 1968 (VI Међународни конгрес о историји и филму: слике револуција 1968.).
} 
(инжењер из пежоа 404 и девојка из дофина). ${ }^{29}$ Одсуство припадника високих друштвених класа, као и чињеница да луксузни аутомобили, попут мерцедеса и поршеа, остају изван граница Кортасарове утопијске заједнице, недвосмислено одређују врсту друштва ка коме се тежи. Чланови мале комуне у „Ауто-путу за југ“ изолују се од остатка света, па се чак и непријатељски односе према сваком новопридошлом возачу и третирају га као уљеза, док унутар своје заједнице негују пожртвованост, добронамерност и алтруизам (Ђурко 1974: 50-52).

Из тог разлога су поједини критичари уместо утопије, у заједници из Кортасарове приповетке препознали «а mirage, [...] the microcosmic caricature of utopia, [...] a parasitic and an artificial form of life» ${ }^{30}$ (Ђурко 1974: 56). Занимљиво је, међутим, да се и спољни свет, односно становници кућа у близини ауто-пута једнако непријатељски опходе према возачима у застоју и одбијају да с њима поделе основне животне намирнице. Оваква Кортасарова концепција света лишава ексклузивне кривице возаче у застоју и премешта фокус на човечанство у целини, које се међу собом дели и повинује технологији, а не људскости. Начин приказа појединачних ликова у приповеци доприноси оваквом доживљају света. Читалац не зна имена ликова јер их приповедач доследно ословљава марком и типом аутомобила које поседују, уз евентуалну напомену о професији или старосној доби. Критика у таквој номенклатури препознаје козификацију и обезличење ликова (Ескудеро-Али 2006; Болте 2019: 215) посредством њиховог генеричког представљања (Мартинес Аријас 223; Кесада Вакеро 115). То је сведочанство о недостатку комуникације и усамљености модерног човека (Љасер 1998: 70-71) у тренутку кад машине, уместо личних имена, постају најважнији људски означитељ (Ђурко 1974: 51).

Годар, попут Кортасара, износи врло јасну, отворену и силовиту критику усмерености постојећег друштвеног система ка материјалним вредностима и конзумеризму (Макбин 1968-1969: 38). Изгубивши породицу у саобраћајној несрећи, једна од јунакиња филма тако жали само за својом скупоценом ташном која је нестала у пламену. Класне разлике су посебно истакнуте у ситуацији у којој

\footnotetext{
${ }^{29}$ Роберто Гонсалес Ећеварија (1971: 138) у примитивној заједници „Ауто-пута за југ“ препознаје неку врсту театра света (theatrum mundi) или средњовековног плеса смрти (шп. danza de la muerte).

30 „привид, [...] микрокосмичку карикатуру утопије, [...] паразитски и артифицијелни облик живота“.
} 
се првенство пролаза даје богатијем и лепшем младићу, спрам земљорадника у трактору коме је по саобраћајним прописима требало да припадне. Испразном спектаклу западног друштва Годар супротставља поједностављен приказ двојице чистача, Африканца и Арапина, који једу сендвиче и говоре о стварности живота у трећем свету (Макбин 1968-1969: 41). Гледалац се у први мах може преварити и помислити да Годар ипак види неку, премда слабашну наду у хипи покрету и антибуржоаском племену које се појављује у другој половини филма. Годарово племе, ипак, ни у ком случају није Кортасарова «alternativa utópica a [...] [la] civilización moderna» ${ }^{31}$ (Ламберт 2014). Уколико Кортасар проналази могућност спаса у такозваној „социјалистичкој утопији“, Годарово отпадничко хипи племе једнако је искварено као и буржоазија (Макбин 19681969: 38). Неки од најсуровијих и најдиректнијих приказа насиља у Годаровом филму (силовање девојке и њено касније жртвовање посредством канибалистичког чина изводе чланови племена) смештени су управо у ову наводно антибуржоаску, али једнако материјалистичку и конзумеристичку заједницу. Суровост и бескрупулозност обеју заједница обележавају или чак онемогућавају саму могућност. Блискост је у буржоаском друштву артифицијелна и под влашћу речи, као што је то у сцени с почетка филма, када Корин (Corinne) описује прилично узнемиријуће сексуалне чинове. С друге стране, у антибуржоаском племену, љубав је лишена контакта и усредсређена на материјално, што је посебно видљиво у еротским сценама из Викенда. Оне се, када не подразумевају насиље, одвијају посредством предмета, нпр. велике рибе као фаличког симбола (Макбин 1968-1969: 37-38). За разлику од Кортасарове приповетке, Годарови ликови имају лична имена, неки од њих су и познате историјске личности или књижевни јунаци, попут Емили Бронте (Emily Brontë) и девојке под именом Марија Магдалена (Marie Madeleine), али свеједно остају потпуно деперсонализовани и сведени на представнике одређених идеја и становишта. Чак су и протагонисти само примери апатичности и хистерије, у потпуности празни, вођени примитивним нагонима и лишени приватних живота, што онемогућава емотивну идентификацију гледалаца с њима (Индијана 2012).

Критика друштва не изостаје ни у Коменчинијевом Застоју, и овога пута врло оштра, недвосмислена и свеобухватна, премда на

\footnotetext{
31 „утопијска алтернатива модерној цивилизацији“.
} 
тренутке духовита. Уколико у „Ауто-путу за југ“ утопијска и веома функционална заједница успоставља општи тон приповетке, у Викенду су то два крајње дисфункционална појединца, а у Застоју општу атмосферу одређује постојање дисфункционалне скупине појединаца. Финансијско профитирање у ванредној ситуацији, крађе, насиље и еклатантни недостатак солидарности и људскости помрачују ретке примере појединачног удруживања. Спрам бракова без комуникације, искрености и љубави, прељуба зарад материјалне користи, небриге за друге, сујете и егоизма, веза између младића из комбија и девојке с гитаром представља једини трачак наде у Коменчинијевом филму. Међутим, и та прича има трагичан крај, будући да младића нападне и претуче, а девојку силује неколико младића док група одраслих мушкараца то посматра и свесно одлучује да не жели ништа да предузме. По присуству, учесталости и врсти приказаног насиља Застој и Викенд значајно су експлицитнији и радикалнији него што је Кортасарова приповетка евентуално захтевала, и по томе ближи један другом него свом потенцијалном књижевном предлошку. Епитет „апокалиптичан“ у критици се скоро неизбежно везује уз Годаров Викенд ${ }^{32}$, али би се и Коменчинијев Застој могао описати на исти начин:

[T] he sense of ruination dominates the atmosphere of the film, the repeated small atrocities, the disintegration of manners, the food and water shortage, the pestilential fumes that blow on the highway, the dire conditions in which drivers and passengers find themselves places the film in the tradition of the apocalyptic/catastrophic film ${ }^{33}$ (Руго 2016: 146).

Апокалиптичној атмосфери доприноси чињеница да су, као и у Кортасаровој приповеци, застојем обухваћени сви друштвени слојеви, професије и генерације (Фрејре 2013; Руго 2016: 145). Иако од Коменчинија сазнајемо имена неких ликова, њихова превасходна функција ипак је представљање друштвених, економских или културних групација којима ти ликови припадају. С друге стране, сличност Коменчинијевог проседеа с Годаровом поетиком хаоса

\footnotetext{
32 Упоредити: Остин 1996: 449; Вестбрук 2005: 345; Бекман 2008: 318; Вајтхед 2011: 394; Бек 2013: 157.

33 [У]тисак пропадања доминира атмосфером у филму, учестала мала зверства, дезинтеграција манира, оскудица воде и хране, штетна испарења која се шире ауто-путем, тешки услови у којима се затекну возачи и путници, смештају филм у традицију апокалиптичних филмова / филмова о катастрофи.
} 
може се препознати у појави необичних јунака у крајње апсурдним ситуацијама, попут манекенки које без повода и разлога позирају на крову аутомобила, или двоје ауто-стопера који у сред застоја упорно, премда безуспешно, покушавају да „ухвате“ превоз до Напуља.

Сам чин кретања у Кортасаровој приповеци поприма димензију безглаве јурњаве без циља и смисла. Кретању је супротстављено присилно мировање, које постаје тренутак повратка духу, хуманости и правом животу. Застој, уобичајено схваћен као једно од нужних зала савременог живота, постаје једина могућност смисленог живота и повратка слободи одлучивања о сопственој судбини, супротстављање неумитном и бесмисленом темпу модерног бивствовања. Застој и мировање омогућавају стварање заједнице по мери човека у којој се људи зближавају, па се чак рађа и љубав. То што Кортасар одлучује да застоју ипак дође крај и да се истог тренутка сви врате у своје аутомобиле и заједница расформира (Мартинес Аријас 2015: 222), сведочи о пишчевом суштински невеселом погледу на стварност. Решење за отуђеност и дехуманизованост савременог друштва можда би се могло наћи, али савремени човек у Кортасаровој приповеци нема слуха за њега и превише се лако препушта струјама које га носе.

Годаров Викенд и „Ауто-пут за југ“ у том погледу приказују две крајности истог става. Хиперболисаном јурњавом без краја и смисла Годар дочарава исту ону опасност константног кретања коју Кортасар открива помоћу мотива присилног мировања. Годарови јунаци прижељкују смрт својих ближњих и дословно газе преко лешева како би себи осигурали материјално благостање. Усредсређујући се на брзину кретања у Годаровом филму, критичари су често Викенд проглашавали неуспелом адаптацијом Кортасарове приповетке (Вита 2012; Лопес Пецолт 2014: 363; Кесада Вакеро 2017: 117). Често се, пак, заборавља да и Годар у општој збрци и хаосу свог филма оставља једну сцену мира и спокоја, сцену заустављања на сеоском имању у којој се изводи Моцартова „Клавирска соната бр. 18“. Овом сценом Годар поручује гледаоцу да се спас може наћи ако се лишимо спектакла и окренемо уметности, миру и себи (Макбин 1968-1969: 43). Имајући у виду проценат Кортасарове приповетке који се проводи у мировању и проценат Годаровог филма који протиче у јурњави, могли бисмо закључити да двојица аутора обрнуто пропорционалним методама постижу исти циљ и шаљу исту поруку модерном свету о потреби да се живот успори, ако не и повремено заустави. 
Проблем кретања представља један од разлога из којих су критичари чешће сматрали Коменчинијев Застој успешном адаптацијом „Ауто-пута за југ“, него што је то био случај с Годаровим Викендом. У Коменчинијевом филму, као и у Кортасаровој приповеци, аутомобили се заустављају на путу из непознатог разлога и остају непомични сатима. Уколико је за Кортасара мировање представљало прилику да се човечанство врати својим коренима и прихвати живот лишен императива материјализма и брзине модерног доба, застој у Коменчинијевом филму открива најмрачније стране људске природе, доводећи капитализам и егоизам до туробног врхунца. По аналогији с Кортасаровом приповетком могло би се очекивати да ће се и живот у Коменчинијевом филму с одгушењем застоја вратити у нормалу. На завршетку филма се најављује разрешење застоја, возачи се ужурбано враћају у кола, стартују моторе аутомобила, али све до краја одјавне шпице нико не полази, нити има било какве промене. Коменчини у том смислу својим гледаоцима нуди најсуморнији поглед на свет и човечанство. За разлику од Кортасара и Годара, који својим читаоцима, односно, гледаоцима, пружају неку могућност спаса, ма колико неизгледна она била, Коменчини негира саму идеју промене. Данијеле Руго (2016: 147) у мирном и привидно једноличном завршетку филма, препознаје крајњи домет Коменчинијевог песимизма:

The end as catastrophic is always also cathartic; it is always [...] a potentially redeeming force. It is this sense of a purification that L'Ingorgo denies [...]. Comencini removes from the idea of the end all evental and revelatory connotations. [...] Comencini understands the end as a flattening force rather than one unlocking change. What is threatening is not its sudden irruption, but its ability to swallow everything in its at persistency, to nally annihilate any project of renewal. The end [...] does not reveal or renew, quite simply the end goes on and on....

Категорије трајања и времена представљају тачку додира „Ауто-пута за југ“ с Викендом и тачку неслагања с Коменчинијевим

\footnotetext{
${ }^{34}$ Колико год био катастрофалан, крај је увек и катартичан; увек потенцијално представља [...] и снагу искупљења. L'ingorgo ускраћује управо тај осећај прочишћења [...]. Коменчини идеју завршетка лишава свих конотација догађаја и откровења. Коменчини види крај пре као сравњујућу силу него као покретање промене. Није нагло наступање краја то што представља претњу, већ његова способност да све прогута својом монотоном упорношћу, да на концу уништи сваку замисао промене. Крај не открива нити обнавља, он просто траје и траје...
} 
Застојем. Трајање застоја у Кортасаровој приповеци и јурњаве у Годаровом филму поприма фантастичне димензије (Кесада Вакеро 2017: 115), док су колоне аутомобила у Коменчинијевом Застоју заустављене током мало вероватног, али ипак могућег временског периода. Застој у „Ауто-путу за југ“ почиње за време летњих врућина, наставља се током облачних дана и првих снежних пахуља и разрешава се тек на пролеће (Ђурко 1974: 49). Како се време у Кортасаровој приповеци премешта из домена мало вероватног у немогуће, а потом и у фантастично или хиперболисано (Болте 2019: 219-222; Лопес Пецолт 2019: 199), тако и ликови све мање воде рачуна о њему, док га на крају скоро у потпуности не занемаре. C друге стране, временски ток у Годаровом филму претежно је линеаран, што се може закључити по смењивању годишњих доба, али се у оквиру те линеарности дани понављају, иду унапред или уназад. Другим речима, «as if time had mysteriously dilated, or frozen into the postapocalyptic synchrony of history's end $»^{35}$ (Индијана 2012). Попут ликова у Кортасаровој приповеци, и Годарови протагонисти на почетку брину како ће стићи на време на читање опоруке, а потом престају да маре за све хировитости времена, иако настављају да јуре. За разлику од „Ауто-пута за југ“ и Викенда, у Коменчинијевом филму време тече на уобичајен начин и остаје у сфери могућег, без обзира на то што застој траје необично дуго - два дана и једну ноћ. Поред тога, учесници Коменчинијевог застоја до краја филма остају свесни трајања и протеклог времена (Болте 2019: 222).

Ако су карактеристике протока времена у „Ауто-путу за југ“ и Викенду блиске, њихове просторне координате се чине посве различитим. Сличност на том плану постоји управо између Кортасарове приповетке и Коменчинијевог Застоја. Радња Кортасарове приповетке се одвија на крајње скученом простору од свега неколико десетина квадратних метара, колико заузима десетак аутомобила. Коменчини просторне одреднице свога филма с једног сегмента пута проширује и на неколико објеката који се налазе тик уз саобраћајницу. Насупрот томе, Годарови протагонисти у свом походу као да прелећу читаву Француску. Разлика у просторним одредницама у Кортасаровој приповеци и Годаровом филму може се објаснити разликом у начину обраде уметничке грађе. Ограниченост и скученост простора који заузима Кортасарова заједница благостања одговарају временској ограничености мирне секвенце с

35 „као да се време мистериозно растегло, или замрзло у постапокалиптичној синхронији краја историје“. 
Моцартовом сонатом у Викенду. Могућност спасења једнако је мала и кратка у оба дела: у Кортасаровој приповеци слобода је могућа једино на крајње ограниченом простору, за мали број људи током неизбежно кратког временског периода, а у Годаровом филму само они који цене уметност могу се спасти за време једне музичке композиције. У Коменчинијевом филму нема спаса, ни у простору, ни у времену, па чак ни у самом завршетку застоја. Италијански режисер нам поручује да су време и простор застоја заправо време и простор наше свакодневице, и да смо заробљени у сопственим животима без могућности спасења. Без могућности да нас неко други избави од сопствене судбине ако сами не одлучимо да изађемо из аутомобила, оставимо иза себе досадашње друштво и запутимо се, ослањајући се на сопствену снагу, ка новом облику живота.

Суштинске поетичке подударности између Кортасарове приповетке „Ауто-пут за југ“, Годаровог филма Викенд и Коменчинијевог филма Застој присутне су на свим пољима од пресудног значаја за тумачење ових дела: од карактеризације ликова, преко динамике догађаја, до представљања просторних и временских односа. Карактеристике појединачних поступака, иако различите, подједнако доприносе критици капитализма и бесмисла савременог живота. Годар и Коменчини можда нису намеравали да сниме адаптације Кортасарове приповетке, или можда нису били свесни посредног утицаја „Ауто-пута за југ“ на њихове филмове, али су гледаоци с разлогом препознали сродан дух и поетичку подударност ових дела. Теоретичари адаптације су се интересовали за оне филмове које су режисери снимали као адаптације одређених књижевних дела, а да публика у њима није препознала изворне текстове. У таквим случајевима се постављало питање јесу ли ови филмови заиста адаптације и није ли неопходно да публика и критика прихвате неко дело као адаптацију не би ли се оно уопште могло поредити са својим књижевним предлошком (в. Хачион 2006: 6, 172). Ако од публике зависи да ли ће неко дело бити сматрано адаптацијом, намеће се питање зашто је мишљење публике и даље мање вредно од намере аутора. Више од пола века откако је објављена смрт аутора, можда је најзад дошло време да се послушају гледаоци. 


\section{БИБЛИОГРАФИЈА}

Бек 2013: Antoine de Baecque. «Jean-Luc Godard et la critique des temps de l'histoire». Vingtième Siècle. Revue d'histoire, 117: 149-164. JSTOR. Web. 07/10/2017.

Бекман 2008: Karen Beckman. «Doing Death Over: Industrial Safety Films, Accidental Motion Studies, and the Involuntary Crash Test Dummy».Discourse, 30.3: 317-347. Project Muse. Web. 07/10/2017. Болте 2019: Rike Bolte. «Fin de cinéma / ¿Fin de ruta? El enlace de Weekend de Jean-Luc Godard (1967) con "La autopista del sur" de Julio Cortázar (1966)». Matthias Hausmann \& Jörg Türschmamm (eds.), La literatura argentina y el cine. El cine argentino y la literatura, Madrid: Iberoamericana / Frankfurt: Vervuert, 211-246.

Вајтхед 2011: Whitehead, Peter. «Weekend». Framework, 52.1: 393-395. JSTOR. Web. 07/10/2017.

Вестбрук 2005: John Westbrook. «Digesting Godard Filming Bataille: Expenditure in Week-end». Contemporary French and Francophone Studies, 9.4: 345-352. Taylor\&Francis Online. Web. 07/10/2017.

Вита 2012: Giulio Vita. «Cortázar y Godard, entre la literatura y el cine». Achtung!, 10.07.2012. Web. 23/10/2019.

Галван 2014: Luis Fernando Galvan. «Julio Cortázar y el cine». En Filme, 28.08.2014. Web. 20/09/2019.

Гили 2004: Jean A. Gili. Luigi Comencini. Roma: Gramese.

Годар 2012: Jean-Luc Godard. Weekend. Criterion Collection, DVD.

Гонсалес Ећеварија 1971: Roberto González Echevarría. «"La Autopista del sur" and the Secret Weapons of Julio Cortázar's Short Narrative». Studies in Short Fiction, 8.1: 130-140. Fondo Julio Cortázar. CRLA ARCHIVOS - Centre de Recherches Latino-Américaines-Archivos. Web. 23/10/2019.

Грас 2016: Dunia Gras. «La marca de Caín, diez años después». Cuadernos hispanoamericanos, 793-794: 102-118. Web. 20/10/2019.

Гpac 2019: Dunia Gras. "The Jam: Cortázar y Caín en 'La autopista del sur'». La literatura argentina y el cine. El cine argentino y la literatura. Matthias Hausmann \& Jörg Türschmamm (eds.). Madrid: Iberoamericana / Frankfurt: Vervuert, 247-276.

Данијеле 2016: Antonio Rosario Daniele. «Meccanismi iperparodici dalla narrazione al cinema: La panne di Dürrenmatt fra Ettore Scola e Alberto Sordi». Between, 6.12: 1-16. Web. 23/10/2019.

Ђурко 1974: Lanin Gyurko. «Alienation and the Absurd in Two Stories by Cortázar». Kentucky Romance Quarterly, 21.1: 43-58. Web. 20/10/2019. 
Езел 2012: Brice Ezell. «Are You in a Film or in Reality? Jean-Luc Godard's 'Weekend' Will Have You Wondering». Pop Matters, 06.12.2012. Web. 23/10/2019.

Ескудеро-Али 2006: María Elvira Luna Escudero-Alie. «Alienación, soledad, y solidaridad en La autopista del sur de Julio Cortázar». Konvergencias literatura, 3. Web. 23/10/2019.

Женет 1982: Gérard Genette. Palimpsestes: la littérature au second degré. Paris: Éditions du Seuil.

Индијана 2012: Indiana, Gary. «The Last Weekend». The Criterion Collection, 14.11.2012. Web. 17/10/2019.

Кахир 2006: Linda Costanzo Cahir. Literature into Film: Theory and Practical Applications. Jefferson, NC: McFarland.

Кенби 1988: Vincent Canby. «Film: From Italy, "Traffic Jam"». The New York Times, March 4, 1988, C. 14. Web. 20/09/2019.

Кесада Вакеро 2017: Marta Quesada Vaquero. «Week-End \& L'ingorgo: dos versiones cinematográficas basadas en «La autopista del sur», de Julio Cortázar y otros sucesos raros». Tibisav López García et al. (coords.), El texto y sus fronteras: Estudios entre literaturas hispánicas y disciplinas artísticas. Madrid: Philobiblion / Asociación de Jóvenes Hispanistas / Universidad Autónoma de Madrid, 111122.

Коменчини 2013: Luigi Comencini. L'ingorgo. Rai. DVD.

Кортасар 2003: Julio Cortázar. "Autopista del sur». Obras completas I. Cuentos, Edición de Saúl Yurkievich, Barcelona: Galaxia Gutenberg / Círculo de Lectores, 529-552.

Кортасар 2007: Julio Cortázar. Cuentos de película. Barcelona: RBA.

Кортасар 2009: Julio Cortázar. El perseguidor y otros cuentos de cine. 1aㅡ edición. Barcelona: RBA.

Кортасар 2011: Julio Cortázar. El perseguidor y otros cuentos de cine. $2^{\text {a }}$ edición. Barcelona: RBA.

Кортасар 2012a: Julio Cortázar. Cartas 1965-1968. Tomo 3. Buenos Aires: Aguilar / Altea / Taurus / Alfaguara.

Кортасар 2012б: Julio Cortázar. Cartas 1969-1976. Tomo 4. Aurora Bernárdez y Carles Álvarez Garriga (eds.). Buenos Aires: Alfaguara. Лајч 2012: Thomas Leitch. «Adaptation and Intertextuality, or, What isn't an Adaptation, and What Does it Matter?». Deborah Cartmell (ed.), A Companion to Literature, Film and Adaptation. Chichester, UK: Wiley-Blackwell, 87-104.

Ламберт 2014: Aline Lambert. «Cortázar, cine y literatura. «La autopista del sur» y Week-end (JL Godard)». Culture. [s.p.] Web. 23/10/2019. 
Лопес Пецолт 2014: López Petzoldt, Bruno. Los relatos de Julio Cortázar en el cine de ficción (1962-2009). Madrid: Iberoamericana / Frankfurt: Vervuert.

Љacep 1998: Eusebio Llácer. «Relaciones espacio-temporales en tres cuentos de Cortázar: "La autopista del sur", "Las babas del diablo" y "Cartas de mamá"». Études romanes de Brno, 47.19: 69-75. Web. 20/10/2019.

Maje 1985: José Agustín Mahieu. «Cine y literatura: la eterna discusión». Cuadernos hispanoamericanos, 420: 175-184.

Макбин 1968-1969: James Roy Macbean. «Godard's Week-End, or the Self Critical Cinema of Cruelty». Film Quarterly, 22.2: 35-43. JSTOR. Web. 23/10/2019.

Мартинес Аријас 2015: Jack D. Martínez Arias. «Pendiendo de la maquinaria: autos y hombres en "La autopista del sur" de Julio Cortázar». A Contracorriente, 12.3: 220-239. Dialnet Unirioja. Web. 23/10/2019.

Матас 1973: Julio Matas. «El contexto moral en algunos cuentos de Julio Cortázar», Revista Iberoamericana, 39.84-85: 593-609. Web. 23/10/2019.

Мекфарлан 2007: Brian McFarlane. «Reading film and literature». Deborah Cartmell \& Imelda Whelehan (eds.), The Cambridge Companion to Literature on Screen. Cambridge: Cambridge University Press, 15-28.

Молитерно 2008: Gino Moliterno. Historical Dictionary of Italian Film. Lanham, Md.: Scarecrow Press.

Нејферт 2003: Agustín Neifert. Del papel al celuloide: Escritores argentinos en el cine. Buenos Aires: La crujía.

Остин 1996: Mark Osteen. «Children of Godard and Coca-Cola: Cinema and Consumerism in Don DeLillo's Early Fiction». Contemporary Literature, 37.3: 439-470. JSTOR. Web. 07/10/2017.

Пералес Контрерас 2014: Jaime Perales Contreras. «Filmando la autopista del sur». Literal 37: [s.p.] Web. 20/09/2019.

Руго 2016: Daniele Rugo. «The end goes on... The desert, the jam and the last days of Italy». Roberto Cavallini (ed.), Requiem for a Nation. Religion and Politics in post-war Italian Cinema. Milan: Mimesis International, 135-148.

Сандерс 2006: Julie Sanders. Adaptation and Apropriation. London; New York: Routledge.

Седењо Валдељос 2014: Ana María Sedeño Valdellós. «Cine у extrañamiento narrativo en las adaptaciones fílmicas de Julio 
Cortázar».Sur, 4, Ejemplar dedicado a Homenaje a Julio Cortázar: 87-93. Dialnet.Unirioja. Web. 23/10/2019.

Тири \& Винокур де Тири 1968: Néstor Tirri \& Sara Vinocur de Tirri. «Prólogo». Noé Jitrik et al. (eds.), La vuelta a Cortázar en nueve ensayos. Buenos Aires: Carlos Pérez, 7-11.

Фалдини \& Фофи 1984: Franca Faldini \& Goffredo Fofi. Il cinema italiano d'oggi, 1970-1984: raccontato dai suoi protagonisti. Milano: A. Mondadori.

Фернандес 2014: Francisco J. Fernández. «[Centenario de Cortázar, 1914-2014] Julio Cortázar en la autopista del sur». Alta Fidelidad, 07.08.2014. Web. 20/09/2019.

Фернандес \& Сабанес 2014: Mariángeles Fernández \& Diego Sabanés. «Julio Cortázar y el cine: ventanas a lo insólito». Impossibilia, 7: 102-120. Web. 06/05/2018.

Ферфакс 2017: Daniel Fairfax. «End ofStory, End ofCinema: Weekend(JeanLuc Godard, 1967)». Senses of cinema, 82. Web. 23/10/2019.

Фpejpe 2013: Héctor J. Freire «Cortázar a través del cine». Topía. [s.p.] Web. 20/09/2019.

Фулвуд 2015: Natalie Fullwood. Cinema, Gender, and Everyday Space. Comedy, Italian Style. New York: Palgrave Macmillan.

Фурније Ланцони 2008: Rémi Fournier Lanzoni. Comedy Italian style: the golden age of Italian film comedies. New York: Continuum.

Хачион 2006: Linda Hutcheon. A Theory of Adaptation. New York: Routledge. 


\title{
JULIO CORTÁZAR’S «THE SPUTHERN THRUWAY» ON FILM, OR ADAPTATIONS THAT MIGHT NOT BE ADAPTATIONS AT ALL
}

\begin{abstract}
Summary
Jean-Luc Godard's film Weekend (1967) and Luigi Comencini's film Traffic Jam (1979) are most often considered to be adaptations of Julio Cortázar's short story «The Southern Thruway» (1966). Yet neither of these motion pictures fulfills one of the most important criteria of any adaptation - a statement of the author's intention. Godard wasn't acquainted with Cortázar's short story, although he came across a script written after «The Southern Thruway». On the other hand, Comencini knew of Cortázar's story, but swore that he had never read it. This paper seeks to give an answer to the question of whether these films could nevertheless be considered adaptations on the basis of poetic similarities and the judgement of the viewers.
\end{abstract}

Keywords: Julio Cortázar, Jean-Luc Godard, Luigi Comencini, «The Southern Thruway», Weekend, Traffic Jam, adaptation, appropriation. 